\title{
AMS RADIOCARBON AND VARVE CHRONOLOGY FROM THE ANNUALLY LAMINATED SEDIMENT RECORD OF LAKE MEERFELDER MAAR, GERMANY
}

\author{
Achim Brauer • Christoph Endres • Bernd Zolitschka • Jörg FW Negendank \\ GeoForschungsZentrum (GFZ), Projektbereich 3.3, Sedimente und Beckenbildung, Telegrafenberg, D-14473 Potsdam, \\ Germany. Email: brau@gfz-potsdam.de.
}

\begin{abstract}
The Holocene varve chronology of annually laminated sediment sequences from Lake Meerfelder Maar agree for most of the record with dendro-calibrated accelerator mass spectronomy radiocarbon dates from the same site. Only between 9710 and $9950 \mathrm{cal}$ BP does an offset of $240 \mathrm{yr}$ appear between both data sets. At this position, a micro-disturbance in the varve succession has been detected by thin section analyses and was quantified in terms of missing varves. A comparison with the nearby record from Lake Holzmaar, as well providing high resolution AMS ${ }^{14} \mathrm{C}$ and varve chronologies, revealed that such gaps (ca. $2 \%$ in time for the entire Holocene) are exceptional for these long-varved maar lake records. Moreover, since sections of missing years appear for both profiles at different stratigraphic positions, a combination of both the Meerfelder Maar and Holzmaar records enables us to bridge erroneous zones in varve chronologies. This confirms the high potential of two long-varved records in close vicinity to each other for the elimination of dating errors and for increasing chronological precision at a time resolution that is normally regarded as within the counting errors. Late Glacial varve and ${ }^{14} \mathrm{C}$ data beyond the dendro-calibration from Meerfelder Maar and their tentative tele-connections to other high resolution data sets reveal unexplained age discrepancies in the calendar year time scale of about 200 years.
\end{abstract}

\section{INTRODUCTION}

Lacustrine sediment archives are an important tool for studying the palaeoclimatic and palaeoenvironmental history on continents because of the large variety of proxy data they provide. One basic prerequisite, however, is a precise and reliable chronology often based on radiocarbon dating. Long laminated lake sediment profiles have, in addition, the possibility of independent dating: varve chronology. This provides not only a potential to contribute to the extension of the tree ring ${ }^{14} \mathrm{C}$ calibration curve, which presently reaches back to 11,871 cal BP (Kromer and Spurk 1998) but also increases the precision of dating certain lake sediments. This has been shown earlier for Lake Holzmaar, Germany (Hajdas et al. 1995a, this issue), Lake Soppensee, Switzerland (Hajdas et al. 1993, this issue), Lake Gościąż, Poland (Goslar et al. 1995, this issue), the stacked Swedish varve chronology (Wohlfarth et al. 1995, this issue), and more recently, Lake Suigetsu, Japan (Kitagawa and van der Plicht 1998a, 1998b, this issue). However, results of lake sediment dating sometimes appears to be contradictory, especially considering the Late Glacial and its last climate deterioration, the Younger Dryas. Refinements, re-examinations, and re-evaluations as well as the presentation of new lacustrine profiles improved the understanding of some of these discrepancies. An age of 11,500$11,600 \mathrm{cal}$ BP for the Younger Dryas/Holocene transition has now generally been accepted (Gulliksen et al. 1998). The beginning of the Younger Dryas is still not covered by tree-ring calibration, but a reliable age between 12,600 and 12,700 cal BP has been reported from Lakes Gościąż (Goslar and Madry 1998) and Meerfelder Maar (Brauer et al. 1999a). Evaluating the remaining small discrepancies of Late Glacial calendar year time scales from different archives still needs to be improved by defining suitable correlation horizons and by obtaining more high resolution radiocarbon data from varved records (Brauer et al. 1999b).

In this study, we present a new accelerator mass spectronomy radiocarbon dataset from the annually laminated lake sediment profile from Lake Meerfelder Maar in the Eifel region of Germany. This site was chosen because of the presence of a long continuous varve succession from about 1500 to 14,200 cal BP and because Meerfelder Maar is located in close vicinity to Lake Holzmaar. Both records contain two tephra layers. Their correlation provides a means of independent control and allows the detection of possible errors in either of the chronological datasets. 


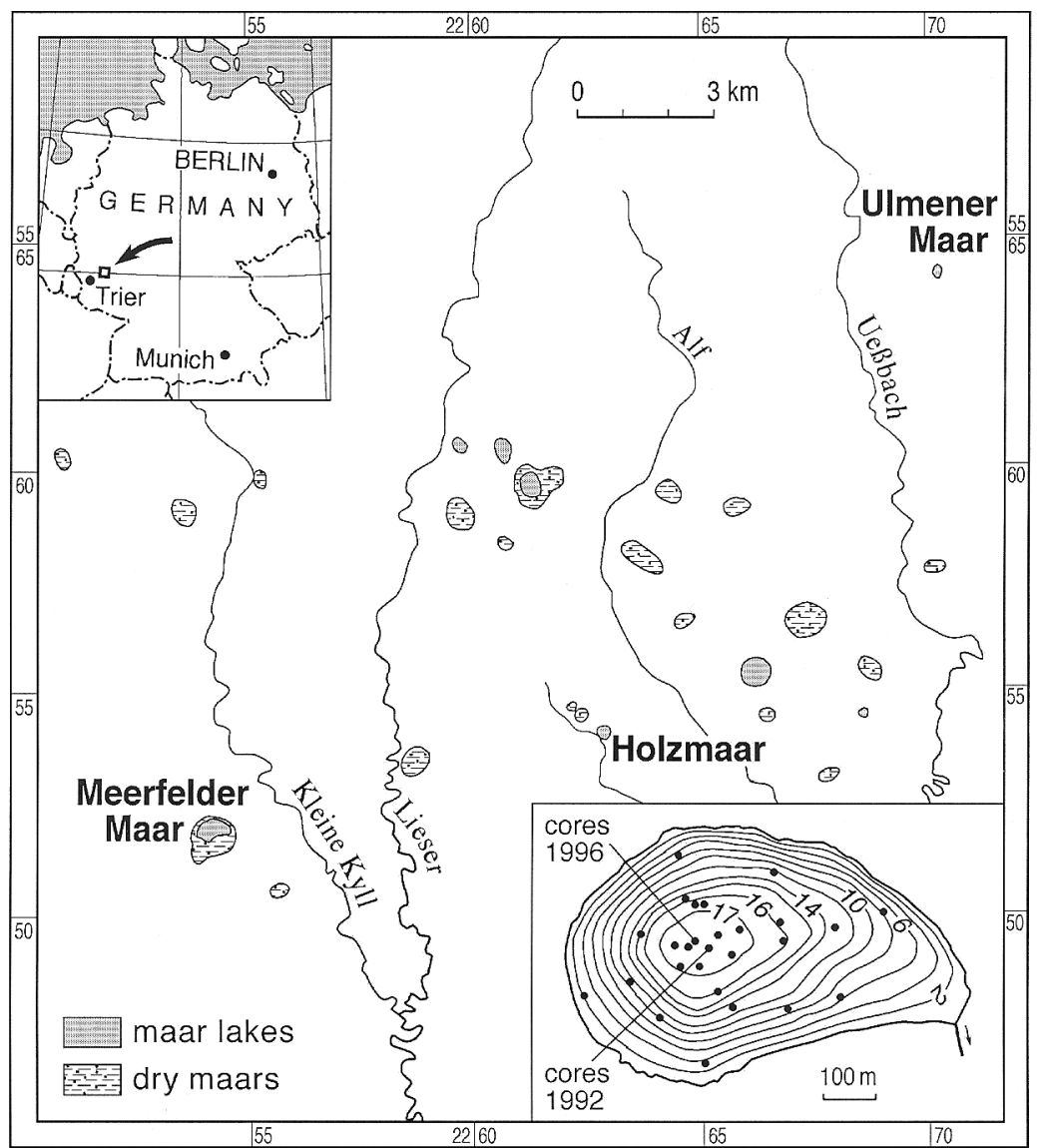

Figure 1 Location of Lake Meerfelder Maar (MFM) within the Westeifel Volcanic Field and bathymetric map of the lake including all drilling locations. The series of five parallel cores from 1996 used for the present study is marked only with one circle and indicated by an arrow.

\section{MATERIAL AND METHODS}

\section{Site and Sediments}

Lake Meerfelder Maar (MFM) is a small maar lake of volcanic origin in the Westeifel, western Germany (Figure 1). It belongs to the Quaternary Westeifel Volcanic Field, which consists of 250 eruption centers, at least 50 of them being maars (Büchel and Krawczyk 1986). Presently, eight of the maar craters are filled with water, including Lakes MFM and Holzmaar (HZM), with MFM located about $10 \mathrm{~km}$ west of HZM (Figure 1). MFM, situated at $336 \mathrm{~m}$ above sea level (asl), has a surface area of $0.248 \mathrm{~km}^{2}$ and a maximum depth of $18 \mathrm{~m}$. The lake basin only covers one third of the entire crater while the other part is covered by delta sediments deposited by a stream (Meerbach) entering from the south. There are no calcareous rocks present within the catchment, so MFM is a softwater lake. The lake is currently eutrophic, but tended to be hypertrophic several times in this century because of intensive human activity in the catchment area. Age determinations of the MFM volcanic eruption are rather rough, but a minimum age of 35,000 cal BP can be regarded as certain 
(Zolitschka et al. 1995). Numerous sediment cores have been obtained from MFM, with the longest one $(45 \mathrm{~m}$ ) still not reaching the crater bottom (Irion and Negendank 1984; Negendank 1989; Negendank et al. 1990). In 1996, five new overlapping sediment cores were recovered from the center of the lake (Figure 1) and combined to a composite profile of $11.20 \mathrm{~m}$ in length (Figure 2). The sediment profile displays four main lithological units (Figure 2).

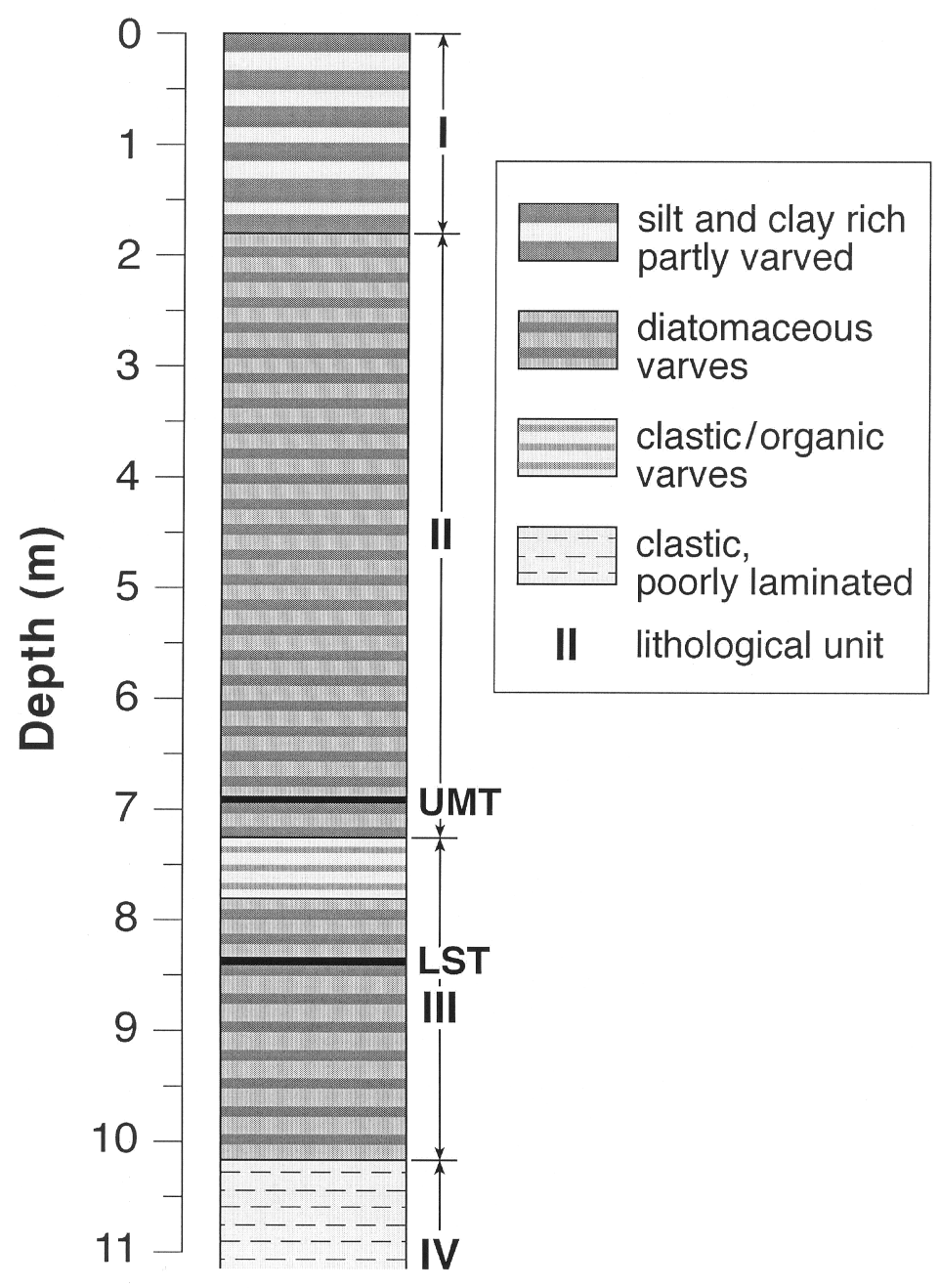

Figure 2 Lake Meerfelder Maar sediment record with four main lithological units and two tephra layers: UMT=Ulmener Maar Tephra; LST=Laacher See Tephra.

The basal part (11.20-10.40 m; lithozone IV) is a reddish-brown minerogenic mud which shows only a few, indistinct $\mathrm{cm}$-thick laminations. The contents in organic matter and diatom frustules are very low. Dry density values of $0.9-1.4 \mathrm{~g} \mathrm{~cm}^{-3}$ reflect the dominance of minerogenic detritus and are the highest of the whole profile. This sediment unit has been deposited under periglacial conditions during the end of the last glaciation and the sharp shift to the following sediment unit marks the transition to the Late Glacial. 
During the Late Glacial (10.40-7.25 m; lithozone III), fine laminations have been continuously formed but their lithological composition is very heterogeneous. Olive-colored, organic-rich sediments are frequently intercalated by sections of reddish-brown minerogenic deposits. In contrast to the basal sediment unit, these minerogenic sediments are annually laminated. One of these sections, dominated by minerogenic sediments, is formed during the second half of the Younger Dryas (YD) and its transition to predominantly organic sedimentation at $7.25 \mathrm{~m}$ depth marks the onset of the Holocene.

Most of the Holocene sediments (7.25-1.80 m; lithozone II) are composed of a finely laminated organic diatomaceous gyttja. The contents in organic carbon range between 7 and $27 \%$. Frustules of planktonic diatoms are abundant and form spring and summer sublayers of the varves, while frustules of littoral diatoms are found in autumn sublayers. Authigenic iron-rich minerals (vivianite, siderite, pyrite) are common throughout the profile and in some periods even form the main minerogenic component.

The uppermost part of the profile $(0-1.80 \mathrm{~m}$; lithozone I) is characterized by higher amounts of minerogenic detritus often deposited in turbidites and detrital layers. This change in deposition was caused by human disturbances in the catchment leading to an increase in soil erosion. Varves occasionally occur but they have not been continuously preserved in the studied cores.

Two tephra layers are recognized within the Late Glacial and the early Holocene part of the profile. The Laacher See Tephra (LST), an important time marker found in many Allerød sediment sequences all over Europe (van den Bogaard and Schmincke 1985), is a 7-cm-thick, dark, coarse sand layer in $8.40 \mathrm{~m}$ depth. The second volcanic explosion is recorded during the Preboreal and assigned to the eruption of the Ulmener Maar volcano which is located about $20 \mathrm{~km}$ NE of MFM (Zolitschka et al. 1995). This Ulmener Maar Tephra (UMT) occurs in $6.91 \mathrm{~m}$ depth and is a 0.3-mm thick layer detectable only after microscopic inspection.

\section{Methods}

A composite profile of the five sediment cores examined was defined by macroscopic comparison and correlation (Figure 2). This first step allowed us to eliminate disturbed sections in any of the cores. Thereafter, a continuous series of large-scale thin sections was prepared from the composite profile. An overlap of at least $2 \mathrm{~cm}$ between each thin section provided a detailed correlation at a single-varve scale confirming the macroscopic correlation. Thus, the whole record was examined microscopically under parallel and polarized light. Magnifications used were $25 \times$ (overview), $100 \times$ (varve counting), and 400-1000× (detail studies). In addition to varve counting, this method enables sediment composition changes as well as possible micro-disturbances to be recognized.

The sediment remaining after sub-sampling for thin sections was used to prepare ${ }^{14} \mathrm{C}$ samples. To avoid obtaining ages that are too old by dating bulk sediment samples which might include reworked material (Olsson 1986, 1991), only terrestrial plant macrofossils have been AMS ${ }^{14} \mathrm{C}$ dated (Zbinden et al. 1989). Following the method described in Hajdas (1993), 2-cm-thick sediment slices have been cut out of all reliably correlated cores (mostly $3-5$ ) in order to get as much sediment as possible per sample. Every ${ }^{14} \mathrm{C}$ sample has been precisely assigned in the corresponding thin section in order to microscopically detect sedimentological evidence for possible reworked material, such as micro-turbidites.

The fresh sediment was dissolved in $10 \% \mathrm{KOH}$ at room temperature for 12-24 $\mathrm{hr}$ and then sieved and washed. If necessary, this procedure was repeated, until all organic and fine sediment material 
was removed. The residue was then examined under a binocular microscope. All identifiable land plant remains were picked out with a fine tweezers. The plant material was washed again carefully. The samples were then stored in distilled water at $4{ }^{\circ} \mathrm{C}$ until further pretreatment and target preparation for AMS measurements. Most of the measurements presented here were performed at the Leibniz Labor, Kiel. Four samples from older cores, which had been previously prepared in the same way and measured at the AMS laboratory in Zürich, have been precisely correlated to the reference profile. Pretreatment and target preparation methods of the Kiel and Zürich laboratories are described in Nadeau et al. (1998) (Kiel) and Bonani et al. (1987) (Zürich). Due to the scarcity of plant remains in MFM sediments, the sample weights were in the range of 0.3-2.0 mg carbon.

\section{RESULTS}

\section{Varve Counting}

Counting of the varves resulted in a floating varve chronology from 1500 to 14,200 cal BP between 1.75 and $9.60 \mathrm{~m}$ sediment depth. Above $1.75 \mathrm{~m}$ and below $9.60 \mathrm{~m}$ the sediment is not continuously varved and, therefore, no precise varve chronology was established. Instead, the thickness of occasionally occurring varves was used for high resolution sedimentation rate determination in order to provide the best possible age estimates for these parts of the record.

Counting from 1.75 down to $6.91 \mathrm{~m}$ sediment depth (Ulmener Maar Tephra, $34 \mathrm{~cm}$ above the Late Glacial/Holocene boundary) was carried out in 1-cm steps providing numbers of varves for each $\mathrm{cm}$ (method 1). The counting error was determined by multiple counting (same investigator) and was found to be $1-2 \%$ in about $80 \%$ of the profile, and not exceeding $4 \%$ for the rest. From $5.56 \mathrm{~m}$ down to $9.60 \mathrm{~m}$ (base of continuous varve series), varve thickness has also been measured (method 2) in addition to simple counting. This method is regarded as more sensitive to detect counting uncertainties especially in sections of low varve thickness in combination with poor varve quality because each varve boundary has to be defined more precisely. In profile sections with good varve quality, the deviation between both methods is also 1-2\% even when counting results have been achieved by different investigators. However, in the only section of poor varve quality and very thin varves $(0.2-$ $0.3 \mathrm{~mm}$ ) between 6.44 and $6.60 \mathrm{~m}$, the discrepancy reached almost $20 \%$. In this case the counts provided by method 2 have been regarded as more reliable.

\section{Radiocarbon Ages}

Between 1.38 and $9.97 \mathrm{~m}$ sediment depth, 51 samples contained sufficient determinable plant material to perform AMS ${ }^{14} \mathrm{C}$ measurements (Table 1). They range from $1010-15,370 \mathrm{BP}$, and their $1 \sigma$ errors range between 30 and $210 \mathrm{yr}$, with one outlier reaching $350 \mathrm{yr}$ (sample \# KIA2525). The relative errors are negatively correlated to the sample sizes (Figure 3 ). The $\delta^{13} \mathrm{C}$ values range between -32.3 and $-20.0 \%$ relative to PDB. Eight samples show deviations from the overall depth- ${ }^{14} \mathrm{C}$ age function towards older ages (Figure 4). Microscopic examination of sediment sections corresponding to these samples show the presence of reworked material, too small to be recognized macroscopically, which was either deposited in the autumn/winter sublayer of a varve or as small turbidite. These dates have been excluded from chronological considerations because they do not represent the age of deposition of the respective sediment section. Three dates, which are obviously too young, are from very small samples (\#KIA927, \#KIA2533, \#ETH15144) and thus might be contaminated by modern carbon. After excluding all doubtful data, $40{ }^{14} \mathrm{C}$ dates remain which lie within the varved part of the profile. 
Table 1 Results of ${ }^{14} \mathrm{C}$ dating and varve counting of MFM sediments ${ }^{\mathrm{a}}$

\begin{tabular}{|c|c|c|c|c|c|c|c|}
\hline Lab nr & $\begin{array}{l}\text { Sediment } \\
\text { depth }(\mathrm{cm})\end{array}$ & $\begin{array}{c}\text { Varves } \\
\text { per sample }\end{array}$ & $\delta^{13} \mathrm{C}$ & $\pm 1 \sigma$ & $\begin{array}{c}{ }^{14} \mathrm{C} \text { age } \\
\mathrm{BP}\end{array}$ & $\pm 1 \sigma$ & $\begin{array}{c}\text { Varve age } \\
\text { cal BP }\end{array}$ \\
\hline KIA2907 & 138.5 & - & -27.04 & 0.08 & 1010 & 30 & - \\
\hline KIA2906 & 178.5 & 10 & -28.29 & 0.08 & 1270 & 30 & 1615 \\
\hline KIA 947 & 207.0 & 8 & -27.86 & 0.12 & 1970 & 40 & 2050 \\
\hline KIA2905 & 228.5 & 14 & -27.57 & 0.11 & 2110 & 30 & 2205 \\
\hline KIA2904 & 238.5 & 11 & -28.97 & 0.18 & 2160 & 30 & 2270 \\
\hline KIA2903 & 268.5 & 18 & -28.11 & 0.10 & 2770 & 50 & 2640 \\
\hline KIA2901 & 288.0 & 35 & -27.44 & 0.12 & 2720 & 40 & 2950 \\
\hline KIA2900 & 308.0 & 33 & -29.32 & 0.12 & 3220 & 60 & 3310 \\
\hline KIA 946 & 358.0 & 39 & -30.67 & 0.11 & 3900 & 50 & 4280 \\
\hline KIA 945 & 388.0 & 29 & -27.75 & 0.15 & 4340 & 60 & 4830 \\
\hline KIA 944 & 408.0 & 59 & -28.76 & 0.23 & 4600 & 60 & 5360 \\
\hline ETH15136 & 424.0 & 27 & -24.30 & 1.20 & $5470^{\mathrm{b}}$ & 65 & 5700 \\
\hline ETH15137 & 430.0 & 25 & -22.60 & 1.20 & 5190 & 95 & 5750 \\
\hline KIA 941 & 492.0 & 37 & -29.28 & 0.13 & 5820 & 100 & 6630 \\
\hline KIA 940 & 502.0 & 25 & -25.01 & 0.11 & 5960 & 70 & 6790 \\
\hline ETH15139 & 505.0 & 30 & -26.20 & 1.10 & 6145 & 85 & 6830 \\
\hline KIA 939 & 512.0 & 27 & -31.15 & 0.34 & 6030 & 110 & 6930 \\
\hline KIA 938 & 541.0 & 45 & -23.44 & 0.19 & 6550 & 80 & 7440 \\
\hline KIA 937 & 550.5 & 49 & -26.55 & 0.27 & 6870 & 80 & 7630 \\
\hline KIA 936 & 570.5 & 54 & -31.09 & 0.23 & 7170 & 140 & 8085 \\
\hline KIA 935 & 580.5 & 34 & -25.70 & 0.13 & 7810 & 80 & 8345 \\
\hline KIA 934 & 600.5 & 57 & -25.53 & 0.14 & $8270^{\mathrm{b}}$ & 80 & 8770 \\
\hline KIA 932 & 610.5 & 40 & -30.34 & 0.23 & 8080 & 130 & 9020 \\
\hline KIA 933 & 610.5 & 40 & -30.01 & 0.12 & 8040 & 130 & 9020 \\
\hline KIA 931 & 620.5 & 35 & -27.77 & 0.13 & 8020 & 190 & 9180 \\
\hline KIA 930 & 630.5 & 40 & -25.34 & 0.19 & $8880^{\mathrm{b}}$ & 90 & 9390 \\
\hline KIA 929 & 681.0 & 31 & -25.73 & 0.16 & 9770 & 120 & 10,830 \\
\hline KIA2538 & 689.0 & 33 & -26.97 & 0.62 & 9610 & 40 & 10,970 \\
\hline KIA 928 & 701.0 & 36 & -26.00 & 0.07 & 9660 & 90 & 11,160 \\
\hline KIA2896 & 707.0 & 37 & -26.93 & 0.20 & 10,310 & 60 & 11,260 \\
\hline KIA2537 & 711.0 & 51 & -29.30 & 0.56 & 10,000 & 120 & 11,340 \\
\hline KIA2536 & 719.0 & 34 & -25.39 & 0.62 & 10,300 & 90 & 11,490 \\
\hline KIA 927 & 721.0 & 35 & -29.30 & 0.27 & 9510 & 220 & 11,530 \\
\hline ETH15144 & 771.0 & 20 & -27.00 & 1.20 & 9685 & 105 & 12,150 \\
\hline KIA2535 & 789.5 & 19 & -20.00 & 0.56 & $13,870^{\mathrm{b}}$ & 90 & 12,320 \\
\hline KIA2895 & 823.5 & 18 & -28.62 & 0.17 & $11,910^{\mathrm{b}}$ & 130 & 12,650 \\
\hline KIA2534 & 825.5 & 20 & -23.06 & 1.50 & $13,770^{\mathrm{b}}$ & 80 & 12,670 \\
\hline KIA2894 & 829.5 & 67 & -24.89 & 0.13 & 11,130 & 90 & 12,750 \\
\hline KIA2533 & 831.5 & 61 & -25.68 & 1.57 & 10,740 & 120 & 12,820 \\
\hline KIA2532 & 918.5 & 8 & -27.69 & 1.68 & 12,050 & 80 & 13,840 \\
\hline KIA2531 & 920.5 & 8 & -27.31 & 0.57 & 12,100 & 80 & 13,850 \\
\hline KIA2530 & 922.5 & 6 & -27.91 & 0.59 & 11,950 & 80 & 13,860 \\
\hline KIA2529 & 924.5 & 15 & -28.43 & 0.69 & 11,880 & 80 & 13,870 \\
\hline KIA2892 & 932.5 & 19 & -24.92 & 0.32 & 12,660 & 70 & 13,930 \\
\hline KIA2528 & 934.5 & 17 & -26.79 & 0.57 & 11,980 & 100 & 13,950 \\
\hline KIA2527 & 942.5 & 10 & -27.15 & 0.99 & 12,060 & 100 & 14,000 \\
\hline KIA2526 & 944.5 & 13 & -32.31 & 1.13 & $13,240^{\mathrm{b}}$ & 100 & 14,010 \\
\hline KIA2525 & 948.5 & 13 & -30.04 & 1.15 & $15,370^{\mathrm{b}}$ & 210 & 14,045 \\
\hline KIA2891 & 950.5 & 14 & -26.37 & 0.30 & 12,320 & 90 & 14,060 \\
\hline KIA2524 & 952.5 & 14 & -28.12 & 0.57 & 12,340 & 90 & 14,070 \\
\hline KIA2890 & 996.5 & 10 & -29.52 & 0.25 & 11,930 & 160 & 14,315 \\
\hline
\end{tabular}

a Lab numbers beginning with "KIA" were measured at Leibniz-Laboratorium, Kiel, and lab numbers beginning with "ETH" were measured at AMS Laboratory of ETH Zurich. ${ }^{14} \mathrm{C}$ ages are expressed as conventional ages (Stuiver and Polach 1977). In the shaded area, a correction of $+240 \mathrm{yr}$ was applied to the varve chronology. For further details, see text.

${ }^{b}$ Dates rejected due to reworked organic material 


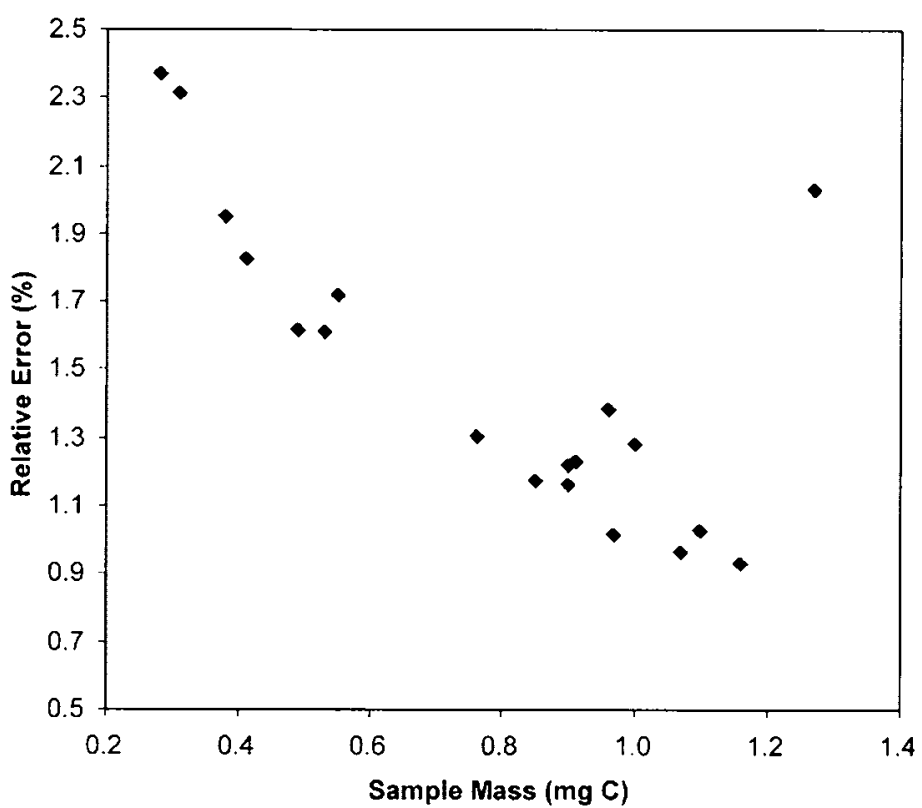

Figure 3 Relative errors of AMS ${ }^{14} \mathrm{C}$ measurements as a function of sample weights

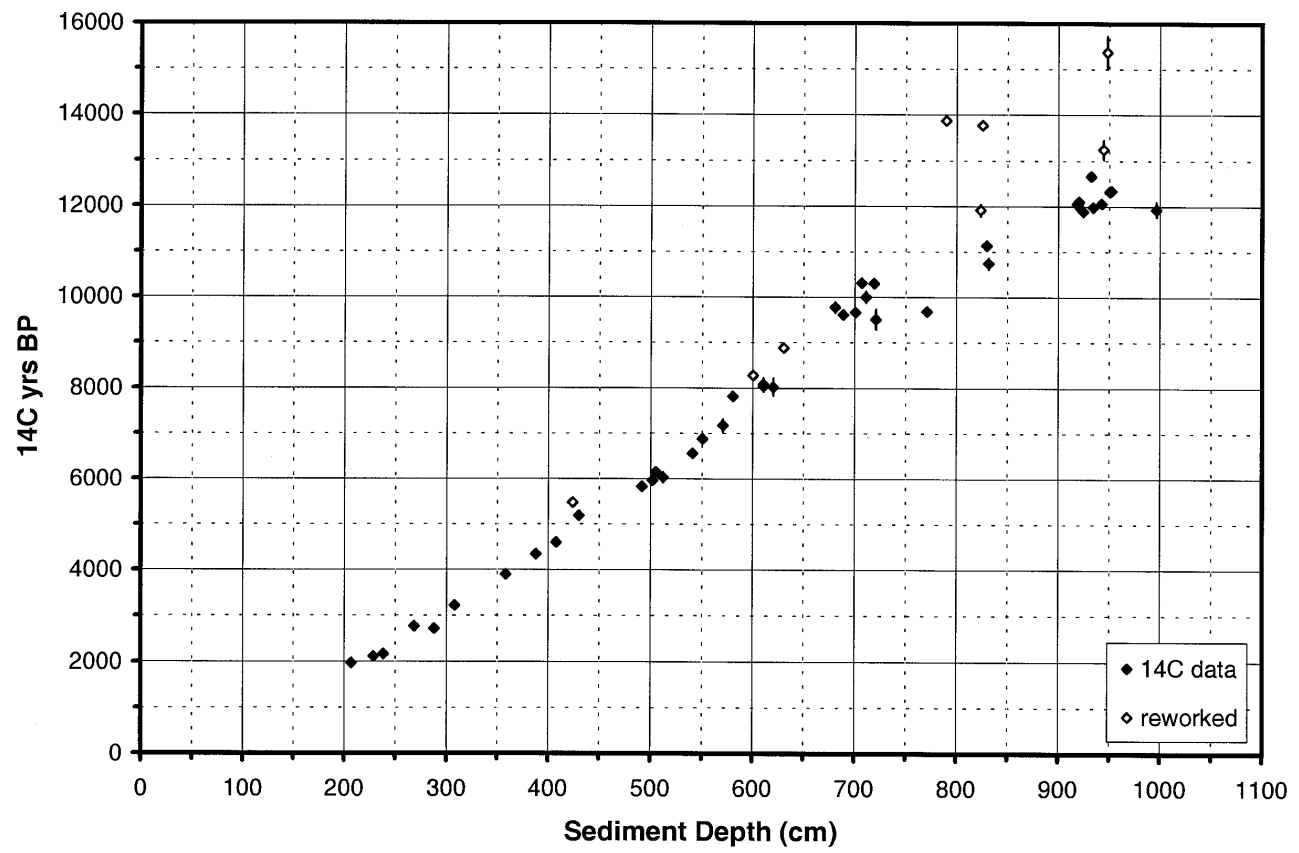

Figure 4 Sediment depth versus ${ }^{14} \mathrm{C}$ ages of MFM as given in Table 1. Unless indicated, $1 \sigma$ errors of the ${ }^{14} \mathrm{C}$ measurements are smaller than data symbols. 
Unfortunately, it was not possible to find terrestrial macrofossils directly at the base or top of the LST. The closest sample to the LST is \#KIA2533 (77 varves above) with a ${ }^{14} \mathrm{C}$ age of $10,740 \pm 120$ BP. However, because of its very small sample size, it appears to be too young. The neighboring sample is \#KIA2894 (138 varves above). Its ${ }^{14} \mathrm{C}$ age is $11,130 \pm 90 \mathrm{BP}$ which is in agreement with high precision ${ }^{14} \mathrm{C}$ dates of trees buried by the Laacher See ash near the eruption center (mean age $11,063 \pm 12$ BP; Friedrich et al. 1999). ${ }^{14} \mathrm{C}$ ages closest to UMT are $9660 \pm 90$ BP (KIA928, 151 varves below) and $9610 \pm 40 \mathrm{BP}$ (KIA2538, 39 varves above).

\section{Radiocarbon Versus Varve Ages}

Two methods have been applied to relate the floating MFM chronology to a calendar year time scale. First, all ${ }^{14} \mathrm{C}$ data from the period before the Ulmener Maar Tephra (UMT) were matched to the treering calibration curve by the $\chi^{2}$ method. This results in an age of 10,760 cal BP for the (UMT), which is younger than previous varve ages of $11,000 \pm 110 \mathrm{cal} \mathrm{BP}$ from HZM (Zolitschka 1998). Unfortunately, the UMT falls into the $9.5 \mathrm{ka}{ }^{14} \mathrm{C}$ plateau, so that tree ring calibration of ${ }^{14} \mathrm{C}$ dates from the UMT results in a $1 \sigma$ interval larger than the discrepancy to be explained. The second possibility of linking the MFM chronology to a calendar year time scale is to use the UMT age of $11,000 \mathrm{cal}$ BP as a tephrochronological marker. Then, however, ${ }^{14} \mathrm{C}$ ages above $6.44 \mathrm{~m}$ sediment depth become apparently $240 \mathrm{yr}$ too young. There are three possible explanations for this phenomenon:

1. The Holocene ${ }^{14} \mathrm{C}$ samples might have been contaminated with modern ${ }^{14} \mathrm{C}$ resulting in ages that are too young. This, however, is unlikely because all samples were prepared following standard methods that are designed to minimize the possibility of contamination and have been applied successfully in many other studies in the past. Furthermore, the fairly constant nature of the shift, if explained by modern carbon, would imply a constant relative contribution of contamination to the absolute sample masses, which by themselves vary between 0.4 and $1.5 \mathrm{mg} \mathrm{C}$. Thus, the observed discrepancy cannot be explained by sample contamination.

2. The accepted age of $11,000 \mathrm{cal} \mathrm{BP}$ for the UMT is too old, which is unlikely because varve dating of UMT in HZM is well established by multiple counting (Zolitschka 1998). In addition, in the MFM varve chronology, the UMT eruption occurred 590 varves (in HZM 600 varves) after the end of the YD. This climatic signal is well expressed in both lakes (Zolitschka 1998; Brauer et al. 1999) and thus can be used for additional correlation. Since the accepted age for the end of the YD is between 11,500 and 11,600 cal BP (Gulliksen et al. 1998), an age of 11,000 calendar yr for the UMT is assumed to be reliable.

3. Missing years in the MFM varve chronology might be the reason for the observed discrepancy. If the ${ }^{14} \mathrm{C}$ data are considered as correct and matched to the tree-ring curve, both curves agree back to about 9710 cal BP where the offset occurs (Table 1). This is exactly at the section of poorly developed varves $(644-660 \mathrm{~cm})$ that have caused a maximum deviation between repeated counts by different methods. Varves within this section are difficult to distinguish from each other, because they lack a significant influx of minerogenic sediment during autumn and/ or winter. After the spring/summer, diatom blooms follows a thin layer of amorphous and particulate organic matter including authigenic minerals like vivianite and siderite. At the upper end of these varve facies a 1.5 -cm-thick micro-disturbance appears in the profile. After this disturbance, an abrupt change in varve facies occurs: increased minerogenic influx leads to the formation of distinct winter layers containing silt and clay. Probably, both sedimentological features, the micro-disturbance followed by an abrupt facies-change indicate the presence of a small hiatus in the record which might have caused a loss of the missing 240 varves. Using the mean sedimentation rate for the minerogenic-poor varve facies, the missing sediment section is assumed to be about $4-5 \mathrm{~cm}$. 
In conclusion, the offset between MFM varve and ${ }^{14} \mathrm{C}$ chronologies is neither the result of erroneous ${ }^{14} \mathrm{C}$ ages nor the result of previously incorrect dating of the UMT marker layer. The favored alternative explanation for the observed discrepancy is a $4-5 \mathrm{~cm}$ micro-hiatus recognized by microscopic investigation at $644 \mathrm{~cm}$ sediment depth. Because of this reason the MFM varve chronology has been corrected for the missing $240 \mathrm{yr}$ at $9710 \mathrm{cal} \mathrm{BP}$ (Table 1). Only the combination of varve chronology and independent high resolution AMS ${ }^{14} \mathrm{C}$ dating with their matching to the tree-ring data allows to identify and quantify such a small hiatus.

\section{LOCAL CORRELATION}

The presence of another varved record from Lake Holzmaar (HZM) less than $10 \mathrm{~km}$ away provides a unique possibility of correlating two high-resolution ${ }^{14} \mathrm{C}$ - and varve-dated profiles. From HZM, a varve chronology has been established from recent times back to 14,000 cal BP (Zolitschka 1991; 1998) which has been further extended into the Last Glacial Maximum to 22,500 cal BP by counting clastic periglacial varves (Brauer et al. 1994). Hajdas et al. (1995a) presented an AMS ${ }^{14} \mathrm{C}$ data set on terrestrial plant macrofossils from HZM sediments covering the last 14,000 cal yr. Based on these ${ }^{14} \mathrm{C}$ dates and their calibration according to Stuiver and Reimer (1993), Hajdas et al. (1995a) suggested a correction of the HZM varve chronology by $+878 \mathrm{yr}$ within the period between 4500 and 3600 cal BP. More recently, this correction was reduced to about +350 varves by identifying more varves in this section of poor varve preservation in additional cores (Zolitschka 1998). The corresponding period in MFM is well varved and confirms that new correction.

The period between 9710 and $9950 \mathrm{cal}$ BP, corresponding to the section where in MFM the 240-yr hiatus occurs, can be placed without any dating difficulties in the HZM varve sequence. These findings allow us to conclude that such minor disturbances within the varve records of MFM and HZM are caused by local sedimentological processes, probably triggered by different basin morphology and hydrology. Both disturbances are macroscopically not visible and in the range of less than 400 yr. Corrections made in both of the varve chronologies are furthermore confirmed by varve counting in the other record. Including these corrections of the varve data, there is a good agreement between both records and the tree-ring calibration for the entire Holocene (Figure 5).

For the Late Glacial correlation of both records the two tephra layers from Laacher See (LST) and Ulmener Maar (UMT) are used. Varve counts between both tephra layers in the HZM record are 320 less than those in MFM, such that a hiatus of this length within the Younger Dryas has been proposed (Zolitschka 1998; Brauer et al. 1999). As expected, ${ }^{14} \mathrm{C}$ dates from samples in stratigraphically close position to the tephra layers in both records are in good agreement. Based on their own data and literature data of different sites, Hajdas et al. (1995b) gave a mean ${ }^{14} \mathrm{C}$ age of $11,230 \pm$ $40 \mathrm{BP}$ for the LST, which is slightly older than the mean age of $11,063 \pm 12 \mathrm{BP}$ recently given by Friedrich et al. (1999). In MFM, a sample 138 varves above LST is dated at 11,130 \pm 90 BP. Two AMS ages of plant samples associated with UMT at HZM are reported by Hajdas et al. (1995a) as $9515 \pm 75 \mathrm{BP}$ and $9650 \pm 85 \mathrm{BP}$. These dates are in agreement with the two ages for the UMT measured from MFM $(9660 \pm 90 \mathrm{BP}$ and $9610 \pm 40 \mathrm{BP})$.

The combination of both varve and high resolution ${ }^{14} \mathrm{C}$ dating allows us to locate and quantify even short sections (about $2 \%$ of the varved sequences) of unidentified varves in the profiles of MFM and HZM. Since these sections do not occur at the same stratigraphical positions in both records, the combination of both profiles provides a reliable calendar year time scale from the Eifel region (Figure 6). This is further confirmed by independent ${ }^{40} \mathrm{Ar} /{ }^{39} \mathrm{Ar}$ dating of Sanidine crystals from LST yielding $12,900 \pm 400 \mathrm{yr} \mathrm{BP}$ (van den Bogaard 1995), which is in agreement with the date of $12,880 \pm 120 \mathrm{yr}$ BP from MFM (Brauer et al. 1999). 


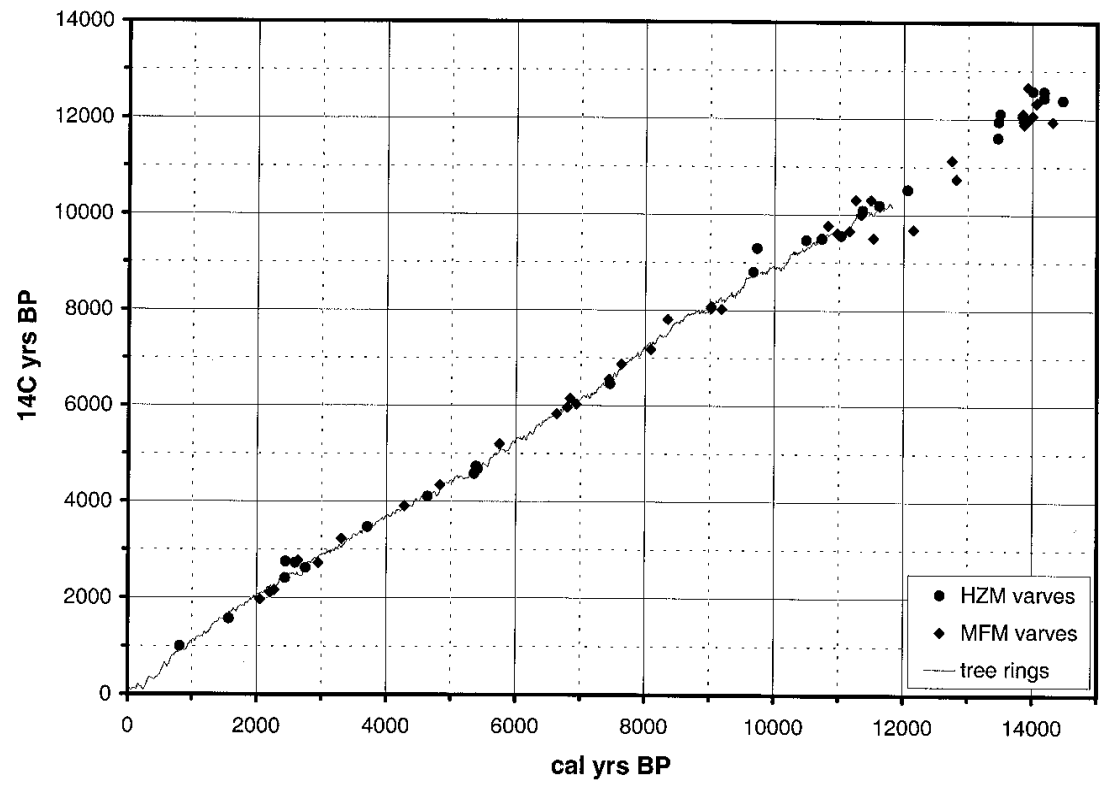

Figure 5 Varve versus ${ }^{14} \mathrm{C}$ ages from MFM and HZM. The tree-ring calibration curve serves as a reference. Varve time scales from MFM and HZM are corrected as discussed in the text.

\section{Global Correlation}

A comparison with ${ }^{14} \mathrm{C}$ chronologies from other sediment archives focuses on the Late Glacial since there is still a need for further terrestrial ${ }^{14} \mathrm{C}$ calibration due to the problems caused by ${ }^{14} \mathrm{C}$ plateaus. Although the present ${ }^{14} \mathrm{C}$ data set from MFM is not dense enough yet for an independent calibration, a link to other records provides information about the range of present uncertainties. In general, MFM and HZM data sets are within the spread found for other lacustrine varved records (Figure 7) as well as for marine data from corals and the Cariaco Basin varves (Figure 8).

The remaining small discrepancies between the different records become visible when using isochronous marker horizons for correlation such as, for example, the LST, especially for the period beyond the tree ring calibration. Accepting the $\mathrm{LST}{ }^{14} \mathrm{C}$ age of $11,063 \pm 12 \mathrm{BP}$ from Friedrich et al. (1999), which is within the $1 \sigma$ confidence interval of the date from the MFM record, and calibrating this age with Cariaco varves (INTCAL98: Stuiver et al. 1998) results in an age for the LST ranging from 13,010-13,200 cal BP. This is 130-320 yr older than the MFM varve age. Another global marker horizon is the first abrupt and short cold spell after the Late Glacial warming, even if we consider that such climatic events do not necessarily have to be synchronous. This cold event is palynologically defined as the Oldest Dryas in MFM (Litt and Stebich 1999), but in many other records is also called Older Dryas (e.g. Björck et al. 1996), or GI-1d according to the INTIMATE stratigraphy based on the GRIP ice core (Björck et al. 1998). Four ${ }^{14} \mathrm{C}$ dates from this event, which has been clearly identified in MFM and correlated to the Greenland ice cores (Brauer et al. 1999), range in between 11,880 \pm 80 and $12,100 \pm 80 \mathrm{BP}($ KIA2529-KIA2532, Table 1$)$. The corresponding calendar year age as determined by varve counting is from 13,800 to $13,900 \mathrm{cal} \mathrm{yr} \mathrm{BP}$ and thus about 200 years younger than in the GISP2 (Alley et al. 1993) and Cariaco Basin records, which exactly match each other (Hughen et al. 1998). On the other hand, ${ }^{14} \mathrm{C}$ dates for this climatic event from the Cariaco Basin record (Hughen et al. 1998; Stuiver et al. 1998) range between 11,898 \pm 68 and 12,084 \pm 83 BP and are in perfect agree- 


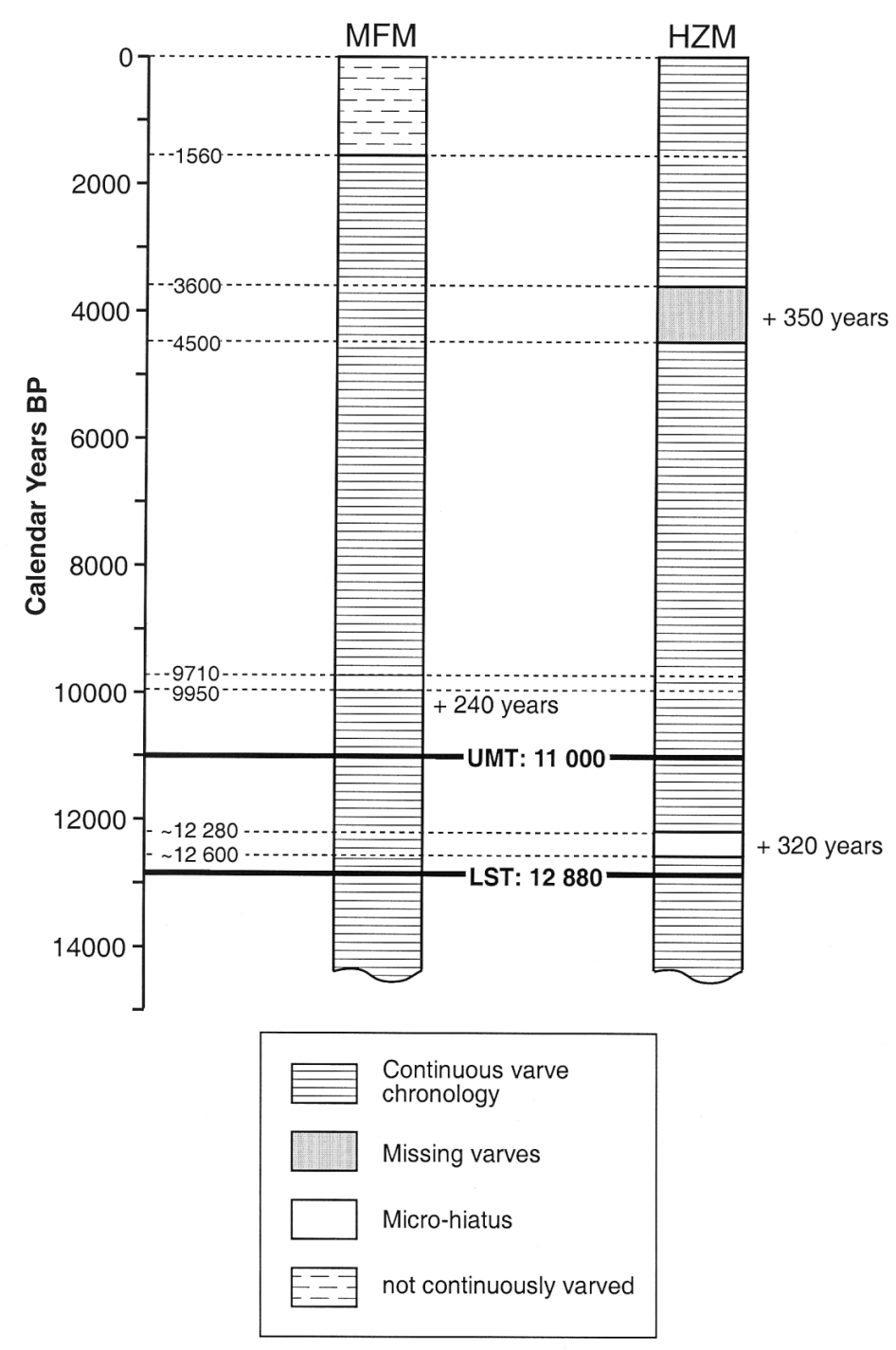

Figure 6 Schematic profiles of MFM and HZM sediment profiles indicating sections of missing varves. The number of missing varves is determined by varve counting in the opposing profile and/or dendro-calibrated ${ }^{14} \mathrm{C}$ data.

ment with MFM data. Thus, the discrepancy of about $200 \mathrm{yr}$ between the MFM and Cariaco Basin record appears only in the calendar year and not in the ${ }^{14} \mathrm{C}$ time scale.

There are two possible explanations for this discrepancy: 1) $\Delta^{14} \mathrm{C}$ variations during the early Late Glacial resulting in a ${ }^{14} \mathrm{C}$ plateau between around 13,800 and 14,100 cal BP (Stuiver et al. 1998). In consequence, the short climatic deterioration would have been a non-synchronous event which is rather unlikely taking into consideration the great similarity of Late Glacial proxy-climatic records, or 2) the observed difference in calendar time scale is an effect of discrepancies between the Cariaco and MFM varve chronologies. This interpretation is supported by the above described age discrep- 


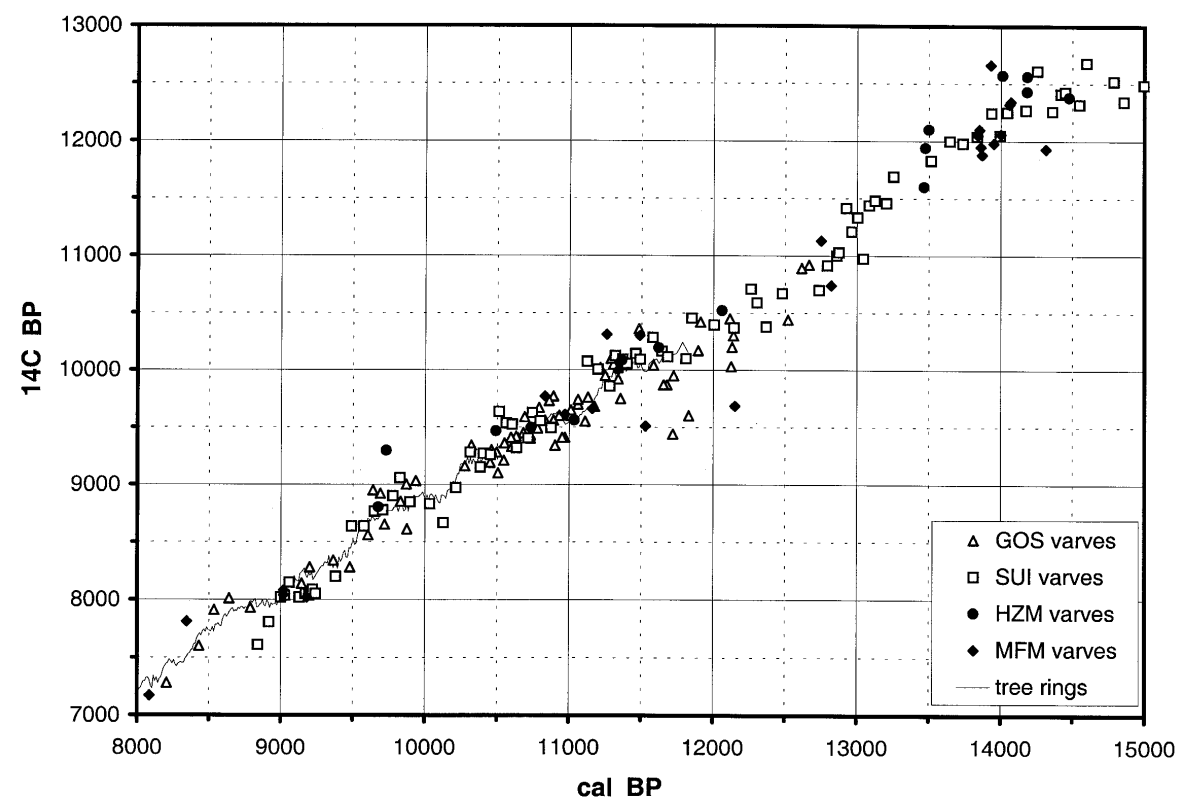

Figure 7 Comparison of MFM and HZM ${ }^{14} \mathrm{C}$ calibration data with other lake sediment archives. GOS = Lake Gościąż, Poland (Goslar et al. 1995); SUI = Lake Suigetsu, Japan (Kitagawa and van der Plicht 1998a, 1998b).

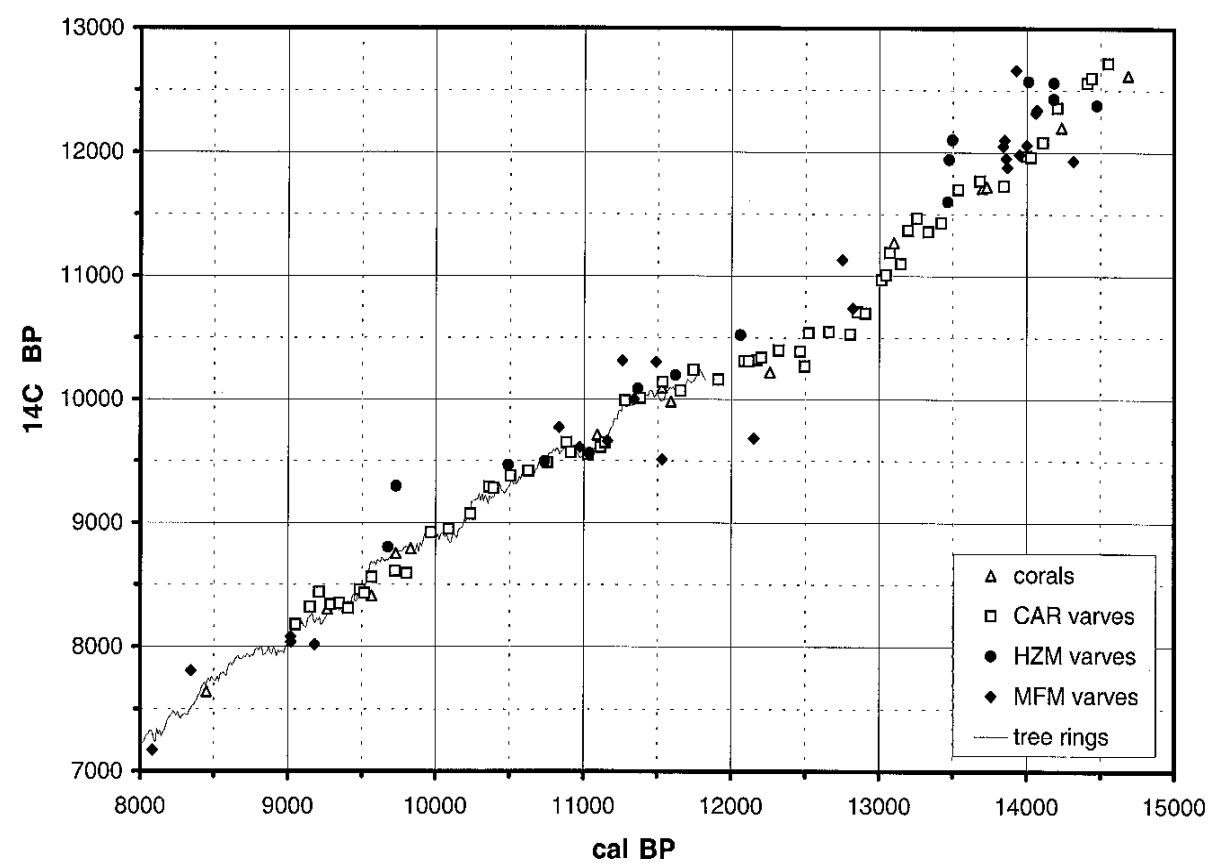

Figure 8 Comparison of MFM and HZM ${ }^{14} \mathrm{C}$ calibration data with marine archives. CAR $=$ Cariaco Basin, Venezuela (Hughen et al. 1998); corals = U-Th-dated coral material (Bard et al. 1998). 
ancy of the LST calendar year age when comparing the MFM varve time scale and the precise ${ }^{14} \mathrm{C}$ date from Friedrich et al. (1999) after calibration with the Cariaco Basin data. At both points of comparison, the LST and the Oldest Dryas/GI-1d Event, the MFM data is in better agreement with the Lake Suigetsu record (Kitagawa and van der Plicht 1998a, 1998b). In the Suigetsu record, 1) a ${ }^{14} \mathrm{C}$ age of $11,030 \pm 55 \mathrm{BP}$, which is close to the LST date of 11,063 $\pm 65 \mathrm{BP}$ (Friedrich et al., forthcoming), yields a calendar year age of 12,874 BP (MFM varve age: $12,880 \mathrm{cal} \mathrm{yr} \mathrm{BP}$ ) and, 2) ${ }^{14} \mathrm{C}$ dates between $11,830 \pm 65$ and $12,040 \pm 55 \mathrm{BP}$ correspond to varve ages between 13,514 and 13,834 cal BP (MFM varve age: 13,800-13,900 cal BP). Since the Cariaco Basin data are confirmed by the GISP2 time scale and since at the moment there are too few ${ }^{14} \mathrm{C}$ data from the Late Glacial available from MFM, this dating problem cannot be solved at this stage. In conclusion, age discrepancies in the range of about $200 \mathrm{yr}$ between Late Glacial calendar-year time scales remain unexplained and require further high-resolution calibration data sets, as well as a better definition of global marker horizons for improving tele-connections of various archives.

\section{ACKNOWLEDGMENTS}

We would like to thank Thomas Litt for his help with determining plant macrofossils. Andreas Hendrich provided support in the preparation of figures. This study has been supported by the Deutsche Forschungsgemeinschaft (DFG) within the SPP "Wandel der Geo-Biosphäre während der letzten 15000 Jahre" (Grant NE 154/29-3). This study is a contribution to the European Lake Drilling Programme (ELDP).

\section{REFERENCES}

Alley RB, Meese DA, Shuman CA, Gow AJ, Taylor KC, Grootes PM, White JWC, Ram M, Waddington ED, Mayewski PA, Zielinski GA. 1993. Abrupt increase in Greenland snow accumulation at the end of the Younger Dryas event. Nature 362:527-9.

Bard E, Arnold M, Hamelin B, Tisnerat-Laborde N, Cabioch G. 1998. Radiocarbon calibration by means of mass spectrometric ${ }^{230} \mathrm{Th} /{ }^{234} \mathrm{U}$ and ${ }^{14} \mathrm{C}$ ages of corals: an updated database including samples from Barbados, Mururoa and Tahiti. Radiocarbon 40(3): 108592.

Bonani G, Beer J, Hofmann H, Synal HA, Suter M, Wölfli W, Pfleiderer C, Junghans C, Münnich KO. 1987. Fractionation, precision and accuracy in ${ }^{14} \mathrm{C}$ and ${ }^{13} \mathrm{C}$ measurements. Nuclear Instruments and Methods in Physics B29:87-90.

Björck S, Kromer B, Johnsen S, Bennike O, Hammerlund D, Lemdahl G, Possnert G, Rasmussen TL, Wohlfarth B, Hammer CU, Spurk M. 1996. Synchronised terrestrial-atmospheric deglacial records around the North Atlantic. Science 274:1155-1160.

Björck S, Walker MJC, Cwynar LC, Johnsen S, Knudsen KL, Lowe JJ, Wohlfarth B, INTIMATE Members. 1998. An event stratigraphy for the Last Termination in the North Atlantic region based on the Greenland ice-core record: a proposal by the INTIMATE group. Journal of Quaternary Science 13(4):283-92.

Brauer A, Hajdas I, Negendank JFW, Vos H, Rein B and Zolitschka B. 1994. Warvenchronologie. Eine Methode zur absoluten Datierung und Rekonstruktion kurzer und mittlerer solarer Periodizitäten. Geowissenschaften 12:325-32.

Brauer A, Endres C, Günter C, Litt T, Stebich M, Negendank JFW. 1999a. High resolution sediment and vegetation responses to Younger Dryas climate change in varved lake sediments from Meerfelder Maar, Germany. Quaternary Science Reviews 18:321-329.

Brauer A, Endres C, Negendank JFW. 1999b. Late Glacial calendar year chronology based on annually laminated lake sediments from Lake Meerfelder Maar, Germany. Quaternary International 61:17-25.

Büchel G, Krawczyk E. 1986. Zur Genese der Dauner Maare im Vulkanfeld Westeifel. Mainzer Geowissenschaftliche Mitteilungen 15:219-38.

Friedrich M, Kromer B, Spurk M, Hofmann J, Kaiser KF. 1999. Paleo-environment and radiocarbon calibration as derived from Late Glacial/Early Holocene tree-ring chronologies. Quaternary International 61:27-39.

Goslar T, Arnold M, Bard E, Kuc T, Pazdur M.F, RalskaJasiewiczowa M, Rozanski K, Tisnerat N, Walanus A, Wicik B, Wieckowski K. 1995. High concentration of atmosphere-rich ${ }^{14} \mathrm{C}$ during the Younger Dryas cold episode. Nature 377:414-17.

Goslar T, Madry W. 1998. Using the Bayesian method to study the precision of dating by the "wiggle matching" procedure. Radiocarbon 40(1):551-60.

Goslar T, Arnold M, Tisnerat-Laborde N, Hatte C, Paterne M, Ralska-Jasiewiczowa M. 2000. Radiocarbon calibration by means of varves versus ${ }^{14} \mathrm{C}$ ages of terrestrial macrofossils from Lake Gościąż and Lake Perespilno, 
Poland. Radiocarbon. This issue.

Gulliksen S, Birks HH, Possnert G, Mangerud J. 1998. A calendar age estimate of the Younger Dryas-Holocene boundary at Kråkenes, western Norway. The Holocene 8(3):249-59.

Hajdas I. 1993. Extension of the radiocarbon calibration curve by AMS dating of laminated sediments of lake Soppensee and lake Holzmaar. PhD. Thesis, ETH Zürich. $147 \mathrm{p}$.

Hajdas I, Ivy SD, Beer J, Bonani G, Imboden D, Lotter AF, Sturm M, Suter M. 1993. AMS radiocarbon dating and varve chronology of lake Soppensee: 6000-12000 ${ }^{14}$ C years BP. Climate Dynamics 9:107-16.

Hajdas I, Zolitschka B, Ivy-Ochs SD, Beer J, Bonani G, Leroy SAG, Negendank JFW, Ramrath M, Suter M. 1995a. AMS radiocarbon dating of annually laminated sediments from lake Holzmaar, Germany. Quaternary Science Reviews 14:37-143.

Hajdas I, Ivy-Ochs SD, Bonani G, Lotter AF, Zolitschka B, Schlüchter C. 1995b. Radiocarbon age of the Laacher See Tephra: 11,230 \pm 40 BP. Radiocarbon 37(2):149-54.

Hajdas I, Bonani G, Zolitschka B. 2000. Radiocarbon dating of varve chronologies: Soppensee and Holzmaar after ten years. Radiocarbon. This issue.

Hughen KA, Overpeck JT, Lehman SJ, Kashgarian M, Southon J, Peterson LC, Alley R, Sigman DM. 1998. Deglacial changes in ocean circulation from an extended radiocarbon calibration. Nature 391:65-8.

Irion G, Negendank JFW, editors. 1984. Das Meerfelder Maar. Courier Forschungsinstitut Senckenberg 65. Frankfurt A.M. 101 p.

Johnsen SJ, Dahl-Jensen D, Dansgaard W, Gundestrup N. 1995. Greenland palaeotemperatures derived from GRIP bore hole temperature and ice core isotope profiles. Tellus 47B:624-629.

Kitagawa H, van der Plicht J. 1998a. A 40,000-year varve chronology from Lake Suigetsu, Japan: extension of the ${ }^{14} \mathrm{C}$ calibration curve. Radiocarbon 40(1):505-15.

Kitagawa H, van der Plicht J. 1998b. Atmospheric radiocarbon calibration to $45,000 \mathrm{yr}$ BP: Late Glacial fluctuations and cosmogenic isotope production. Science, 279:1187-90.

Kitagawa H, van der Plicht J. 2000. Atmospheric radiocarbon calibration beyond $11,900 \mathrm{cal}$ BP from Lake Suigetsu laminated sediments. Radiocarbon. This issue.

Kromer B, Spurk M. 1998. Revision and tentative extension of the tree-ring based ${ }^{14} \mathrm{C}$ calibration 9200 to 11,870 cal BP. Radiocarbon 40(3):1117-25.

Litt T, Stebich M. 1999. Bio- and chronostratigraphy of the Late Glacial in the Eifel region, Germany. Quaternary International 61:5-16.

Nadeau MJ, Schleicher M, Gottdang A, Mouse DJW,
Grootes PM. 1996. Performances and characteristics of the Leibniz-Labor AMS facility mass spectrometer. Radiocarbon 38(1):94.

Negendank JFW. 1989. Pleistozäne und holozäne Maarsedimente der Eifel. Zeitschrift der Deutschen Geologischen Gesellschaft 140:13-24.

Negendank JFW, Brauer A, Zolitschka B. 1990. Die Eifelmaare als erdgeschichtliche Fallen und Quellen zur Rekonstruktion des Paläoenvironments. Mainzer geowissenschaftliche Mitteilungen 19:235-65.

Olsson IU. 1986. Radiometric dating. In: Berglund BE, editor. Handbook of Holocene palaeoecology and palaeohydrology. Chichester: John Wiley \& Sons. p 273-312.

Olsson IU. 1991. Accuracy and precision in sediment chronology. Hydrobiology 214:25-34.

Stuiver M, Reimer PJ. 1993. Extended ${ }^{14} \mathrm{C}$ data base and revised CALIB $3.0^{14} \mathrm{C}$ age calibration program. $R a$ diocarbon 35(1):215-30.

Stuiver M, Reimer PJ, Bard E, Beck JW, Burr GS, Hughen KA, Kromer B, McCormac G, van der Plicht J, Spurk M. 1998. INTCAL98 radiocarbon age calibration, 24,000-0 cal BP. Radiocarbon 40(3):104184.

van den Bogaard P, Schmincke HU. 1985. Laacher See Tephra: a widespread isochronous late Quaternary tephra layer in central and northern Europe. Geological Society of America Bulletin 96:1554-71.

van den Bogaard P. 1995. ${ }^{40} \mathrm{Ar} /{ }^{39} \mathrm{Ar}$ ages of sanidine phenocrysts from Laacher See Tephra (12,900 yr BP): chronostratigraphic and petrological significance. Earth and Planetary Science Letters 133:163-74.

Wohlfarth B, Björck S, Possnert G. 1995. The Swedish time scale: a potential calibration tool for the radiocarbon time scale during the Late Weichselian. Radiocarbon 37(2):347-59.

Wohlfarth B, Possnert G. 2000. AMS radiocarbon measurements from the Swedish varved corals. Radiocarbon. This issue.

Zbinden H, Andrée M, Oeschger H, Ammann B, Lotter A, Bonani G, Wölfli W. 1989. Atmospheric radiocarbon at the end of the last Glacial: an estimate based on AMS radiocarbon dates on terrestrial macrofossils from lake sediment. Radiocarbon 31(3):795-804.

Zolitschka B. 1991. Absolute dating of late Quaternary lacustrine sediments by high resolution varve chronology. Hydrobiology 214:59-61.

Zolitschka B. 1998. Paläoklimatische Bedeutung laminierter Sedimente. Relief, Boden, Paläoklima 13. Berlin, Stuttgart: Gebrüder Bornträger Verlag. 176 p.

Zolitschka B, Negendank JFW, Lottermoser BG. 1995. Sedimentological proove and dating of the early Holocene volcanic eruption of Ulmener Maar (Vulkaneifel, Germany). Geologische Rundschau 84:213-19. 